\title{
Biyoimpedans İğne Probu ile Parçacık Boyut Tespiti
}

\author{
Tuba Denkçeken 10
}

SANKO Üniversitesi, Biyofizik Anabilim Dalı, Gaziantep, Türkiye

Tuba Denkçeken, Dr. Öğr. Üyesi
Illetişim:

Dr. Öğr. Üyesi Tuba Denkçeken

SANKO Üniversitesi, Biyofizik Anabilim Dalı,

Gaziantep, Türkiye

Tel: +900342 2116561

E-Posta: tdenkceken@sanko.edu.tr
Gönderilme Tarihi : 11 Eylül 2018

Revizyon Tarihi : 05 Ekim 2018

Kabul Tarihi : 10 Ekim 2018

\section{ÖZET}

Amaç: Sunulan çalışmanın amacı Biyoimpedans iğne probunun in-vitro doku benzeri ortamında test edilmesidir.

Çalışma Planı: Biyoimpedans iğne probu ile biyoimpedans cihazı bağlanmış ve kHz aralığında spektrumlar kaydedilmiştir. Prop 18Gauge 1.2x89 mm lomper ponksiyon iğnesi kullanılarak dizayn edilmiştir. Prob 1, 2 ve 4 mikrometre boyutundaki polistiren mikroküreciklerde kullanılarak impedans bilgisi kaydedilmiştir. Prob ile doku fantomuna akım gönderilmiş ve ortamın iletkenlik bilgisi elde edilmiştir.

Bulgular: Biyoimpedans iğne probu ile elde edilen özel sinyaller ile parçacık boyutu ayrımı gerçekleştirilmiştir. Doku fantomundaki parçacık boyut bilgisi $50 \mathrm{kHz}$ direnç değeri ile değerlendirilmiştir. Polistiren mikroküreciklerden alınan biyoimpedans spektrumlarına göre parçacık boyutunun artmasıyla direnç değeri artış göstermiştir.

Sonuç: Probun doku fantomundaki parçacık boyut ayrımını doğru bir şekilde belirlemesi ileriki aşamalarda hastaIardan alınan beyin omurilik sıvılarında kültüre gerek duyulmadan Escherichia coli veya Acinetobacter baumanni gibi farklı boyutlara sahip mikroorganizmaların varlığını gerçek zamanlı teşhis etme potansiyeli barındırmaktadır. Ayrıca probun hücre külttürü çalışmalarında da hücre sayısını ve ayrımını yapabilme olasılığı bulunmaktadır.

Anahtar sözcükler: Biyoimpedans, spektroskopi, parçacık boyutu, iğne

\section{PARTICLE SIZE DETECTION BY BIOIMPEDANCE NEEDLE PROBE}

\section{ABSTRACT}

Objectives: The aim of this study was to test the Bioimpedance probe needle on in-vitro tissue phantom.

Study Design: Bioimpedance probe needle that was connected to a bioimpedance measurement device to record spectra in the $\mathrm{kHz}$ range. The probe consists of an 18Gauge $1.2 \times 89 \mathrm{~mm}$ spinal needle. The probe was used for obtaining impedance information about the polystyrene microspheres which were in different diameters; 1, 2 and 4 micrometers. The current was transferred to the phantom and conductivity information was obtained by the probe.

Results: Bioimpedance probe needle allows the discrimination of different particle sizes based on their specific signatures. The sensitivity of the probe to particle size in tissue phantom was tested during the study. Spectroscopic data were evaluated with resistance values at $50 \mathrm{kHz}$ and the information about the particle size in the tissue phantom was obtained. Bioimpedance spectra results which were obtained from polystyrene microspheres showed that the resistance values were increasing while the size of the particle was enlarging.

Conclusion: Due to the highly accurate differentiation of particle size in the tissue phantom, our probe has the potential to be used in the rapid detection of Escherichia coli or Acinetobacter baumannii which have different sized microorganisms in the tapped cerebrospinal fluid without being cultured in real time. In addition, it is possible for the probe to perform cell counting and differentiation in cell culture studies.

Keywords: Bioimpedance, spectroscopy, particle size, needle 
D iyoimpedans Spektroskopi tekniği ile düşük, dokuya herhangi bir zarar vermeyen ve in-vivo koşullarda acısız alternatif akım dokuya gönderilir ve impedans ölçülür. Hücrenin elektriksel eşdeğer devre modelinde intraselüler $\left(R_{\text {intraselüler }}\right)$ ve ekstraselüler $\left(R_{\text {extraselüler }}\right)$ sıvılar ile zardaki iyon kanalları $\left(R_{\text {membran }}\right)$ direnç ile temsil edilirken membranın kendisi yük ayrımı yapan plaka gibi düşünüldüğü için kapasitör $\left(C_{\text {membran }}\right)$ ile temsil edilmektedir (1). Hücreye elektriksel potansiyel uygulandığı zaman yüksek frekanstaki akımlar hücre içinden ve düşük frekanstaki akımlar da hücre dışından akarlar (2). Düşük frekansta hücre yalıtkan gibi davranırken yüksek frekansta ise iletken gibi davranır. Sıfır frekansta akım hücre zarına giriş yapamaz ve hücre dışından akar. İmpedansın (Z) iki bileşeninden biri olan direnç ( $R$ : vücut sıvısının akıma direnmesi) ve diğer bileşen olan reaktans ( $X_{c}=1 / 2 f C$ : hücre zarı ve doku ara yüzeyinin akıma direnmesi) her frekansta $Z^{2}=X_{c}^{2}+R^{2}$ ile hesaplanır. Reaktans, kapasitans ile ilişkili olup kapasitans akımı yumuşatır ve faz kaymasına neden olur. Bu faz kayması hücre, hücre membranının yapısı ve fonksiyonel durumu hakkında bir belirteç olan faz açısı ile tanımlanır ve faz açısının değeri $\arctan \left(\mathrm{X}_{C} / \mathrm{R}\right)$ ile hesaplanır (3-4). Biyoimpedans Spektroskopi ile dokunun iletkenlik parametreleri belirlenebilmektedir (5). Dokunun impedansı frekansa bağlı olarak değişiklik göstermektedir. Hücre membranı ve doku arayüzeyinin kondansatör gibi davranmasından dolayı düşük frekanslarda akım hücre dışından akar. Böylece impedans reaktif bileşen olmadan yüksek direnç özelliği gösterir. Ancak yüksek frekanslarda bu kapasitif etki kaybolur ve akım tüm ortamdan akar ve direnç ise azalır. Yüksek frekanslarda hücre membranı ve doku arayüzeyi kapasitif özelliğini yitirerek intraselüler akımda artış olmaktadır (3). Biyolojik dokular yapılarına bağlı olarak karmaşık elektriksel impedansa sahiptirler (67). Dokuda herhangi bir kanser gelişimi olduğunda kromatin yapı ve mukoza bütünlüğü değişmekte, hücre hacmi genişlemekte buna bağlı olarak hücre dışı alan azalmakta ve çekirdek büyümektedir (8). Dokuda metastatik tümör hücreleri geliştiği zaman zar ve içeriklerinde çeşitli farklılaşmalar oluşmaktadır. Bu farklılaşmalar; yüksek aerobik laktat üretimi, anormal plazma zar geçişleri, hücre bağlantılarının azalması ve yeni antijen oluşumlarıdır. Dokuda neoplastik değişim olduğu zaman hücre içerisinde sodyum, potasyum ve kalsiyum iyon oranlarında değişim olmakta ve bunun sonucunda hücrenin şekli, hareketi ve hücreler arası iletişimde bozulma meydana gelmektedir. Hücrede kanser süresince meydana gelen tüm bu değişimler hücre fizyolojisini etkiler ve dolayısıyla dokunun elektriksel özelliklerini değiştirmektedir (9). Farklı doku tipleri farklı iletkenlik parametreleri sergilemekte olduğundan kanserli hücreler Biyoimpedans Spektroskopi yöntemi ile ayırt edilebilmektedir. Kanser gelişimi sürecinde hücre dışından akan düşük frekans akım aralığında direnç artmakta ve bu da impedans artımına neden olmaktadır (10)\#. Daha önce yapılan çalışmalarda prostat, meme, akciğer ve lenf düğümü kanser teşhisinde biyoimpedans ölçüm tekniği kullanılmıştır (11-14).

Sunulan çalışmada tasarlanan probun doku fantomundaki parçacık boyut ayrımını doğru bir şekilde belirlemesi amaçlanmıştır. Böylelikle ileriki aşamalarda hastalardan alınan beyin omurilik sıvılarında kültüre gerek duyulmadan Escherichia coli veya Acinetobacter baumanni gibi farklı boyutlara sahip mikroorganizmaların varlığını gerçek zamanlı teşhis etme potansiyeli barındırmaktadır. Ayrıca probun hücre kültürü çalışmalarında da hücre sayısını ve ayrımını yapabilme olasıı̆̆ı bulunmaktadır.

\section{Gereç ve yöntem}

In-vitro doku benzeri ortamlarda (su içinde dağılan polistiren mikro boyutta küresel parçacıklar) bioimpedans probu test edilmiştir. Farklı çaplara sahip $(1 \mu \mathrm{m}, 2 \mu \mathrm{m}$ ve $4 \mu \mathrm{m}$ ) polistiren küresel parçacıklardan (Duke Scientific Corp. Kaliforniya, ABD) ölçümler alınmıştır. Seçilen parçacık boyutları arasındaki farklar 2 kat olacak şekilde simüle edilmiştir. Sunulan çalışmada Biyoimpedans iğne probu geliştirilmiş ve in-vitro doku benzeri ortamda probun parçacık büyüklüğüne duyarlılığı test edilmiştir (Şekil 1).

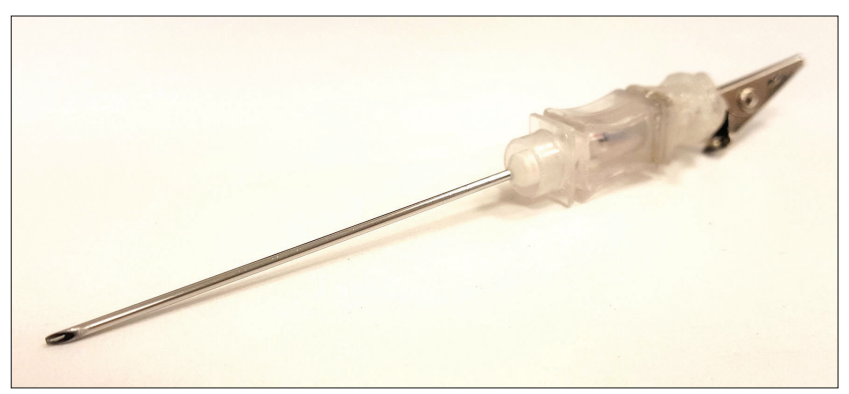

Şekil 1. 18G biyoimpedans probu

Biyoimpedans probu lomper ponksiyon iğnesi ile yapılmıştır. Iğnenin boyutu 18Gauge 1.2x89 mm olup izolasyonu sinyal jeneratörü ve osiloskop kullanılarak sağlanmıştır. Sinyal jeneratöründen iğnenin dışına sinyal verilip iç iğnede sinyal olup olmadığı osiloskop ile tespit edilmiştir. Ortama akım göndermek ve impedans ölçümü için prob ile Biyoimpedans Analizatör (Quadscan 4000, Bodystat Inc.) bağlantısı yapılmıştır.

In-vitro ortama prob ile çoklu (5-50-100-200 kHz) frekanslarda akım verilmiş ve bu akım bilgilerine göre impedans ölçümleri alınmıştır. Ayrıca 50 kHz frekansta Resistans, 
Reaktans ve faz açısı değerleri de kaydedilmiştir. Çalışma süresince elde edilen datalar $50 \mathrm{kHz}$ 'teki direnç datalarına göre değerlendirilmiş ve her ortamdan 10'ar adet ölçüm alınmıştır. Alınan direnç değerleri Kruskal-Wallis testi ile karşılaştırıımış ve $p<0.05$ istatistiksel olarak anlamlı kabul edilmiştir. İstatistiksel değerlendirmeler IBM SPSS Statistics 23 programı kullanılarak yapılmıştır.

\section{Bulgular}

Deneyin ilk aşamasında sistemin farklı parçacık boyutlarına duyarlılığının tespiti için öncelikli olarak bioimpedans probu ile 1, 2 ve 4 mikrometrelik polisitren parçacıklar (20'şer $\mu \mathrm{l}) 180 \mu \mathrm{l}$ su ile seyreltilerek ependorflara konulmuş ve farklı parçacık boyutları için direncin değişiklik gösterdiği belirlenmiş ve buna göre parçacık boyutunun artmasıyla direnç artış göstermiştir (Şekil 2).

Deneyin ikinci aşamasında ise 1, 2 ve 4 mikrometrelik parçacıklar her birinden 60 'şar $\mu \mathrm{l}$ olacak şekilde birbirleri ile karıştırılmış sistemin farklı parçacıklar barındıran ortamlarda duyarlılığı test edilmiştir. Buna göre $1 \mu \mathrm{m}+2 \mu \mathrm{m}, 1$ $\mu \mathrm{m}+4 \mu \mathrm{m}$ ve $2 \mu \mathrm{m}+4 \mu \mathrm{m}^{\prime}$ lik ortamlardan toplam $120 \mu \mathrm{l}^{\prime}$ lik karışım elde edilmiş ve bu karışımlar için direncin değişiklik gösterdiği belirlenmiştir. Buna göre içinde farklı boyutlarda parçacık bulunduran aynı miktarlardaki karışımlarda da iğne probu ile elde edilen direnç değerleri parçacık boyutlarının artmasıyla artış göstermiştir (Şekil 3).

Bu sonuçlara göre aynı miktarlardaki ortamlarda bulunan parçacıkların boyutunun artması ile biyoimpedans iğne probundan elde edilen direnç değeri artış göstermiştir. Aynı zamanda farklı boyutlarda parçacık içeren ortamlarda da yine aynı şeklide direnç artış göstermiştir.

Çalışmamızda kullanılan fantomlardan alınan direnç değerleri karşılaştırıldığında istatistiksel olarak anlamlı fark bulunmuştur ( $p=0.005)$. Farklı çaplara sahip olan bu fantomlar çoklu karşılaştırıldığında ise 1 ve $4 \mu \mathrm{m}$ çapına sahip olanlarda anlamlı fark elde edilmiştir ( $p=0.004)$.

\section{Tartışma}

Biyoimpedans Spektroskopi tekniği ile düşük, dokuya herhangi bir zarar vermeyen ve in-vivo koşullarda acısız alternatif akım dokuya gönderilir ve impedans ölçülür. Bioimpedans spektroskopi tekniği kullanılarak kanser teşhisi çalışmaları (15-18), gerçek zamanlı hücre kültürü çalışmaları (19-20) ve bakteriyel tanımlamalar yapılmaktadır (21-22). Bu çalışma ile Biyoimpedans iğne probu yapımı gerçekleştirilmiş ve prob in-vitro doku fantomunda

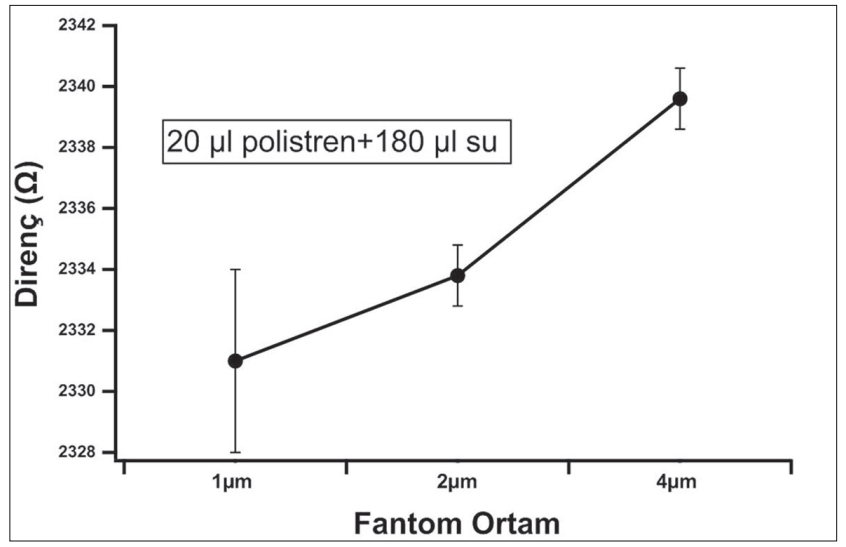

Şekil 2. Bioimpedans probu ile 1, 2 ve 4 mikrometrelik polisitren kürecik direnç ölçüm grafiği

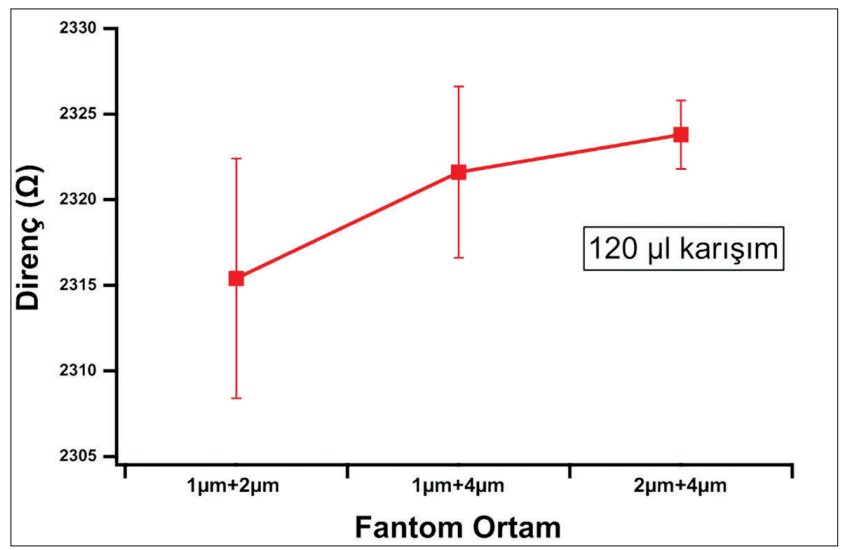

Şekil 3. Bioimpedans probu ile $1 \mu \mathrm{m}+2 \mu \mathrm{m}, 1 \mu \mathrm{m}+4 \mu \mathrm{m}$ ve $2 \mu \mathrm{m}+4 \mu \mathrm{m}^{\prime}$ lik polisitren kürecik direnç ölçüm grafiği

test edilmiştir. Doku fantomu olarak 1, 2 ve $4 \mu$ m çapında polisitren küreciklerde sistemin parçacık büyüklüğüne duyarlıığı incelenmiştir. Parçacık boyutunun artmasıyla küreciklerin dışında akan düşük frekans akım aralığında direnç artış göstermiştir. Bunun nedeni aynı miktardaki ortamlarda parçacık boyutunun küçük olması ile düşük frekanslarda akan akım bu parçacık etrafında daha fazla alana maruz kalmakta ve bu boyutlarda direnç daha az bulunmaktadır. Fakat parçacık boyutunun artması ile birlikte parçacık yüzey alanı artmakta, hücre dışında akan akımın maruz kaldığı alan azalma gösterdiği için düşük frekansta bu hücrelerde direnç artış göstermektedir. Probun doku fantomundaki parçacık boyut ayrımını doğru bir şekilde belirlemesi ileriki aşamalarda hastalardan alınan beyin omurilik sıvılarında 16-24 saat kadar süren kültür prosedürlerine gerek duyulmadan Escherichia coli veya Acinetobacter baumanni gibi farklı boyutlara sahip mikroorganizma varlığını gerçek zamanlı teşhis etme potansiyeli barındırmaktadır. 


\section{Kaynaklar}

1. Hodgkin AL, Huxley AF. A quantitative description of membrane current and its application to conduction and excitation in nerve. The Journal of physiology. 1952;117:500-44. [CrossRef]

2. Schwan HP. Electrical properties of tissue and cell suspensions. Adv Biol Med Phys. 1957;5:147-209.

3. Lukaski HC. Biological indexes considered in the derivation of the bioelectrical impedance analysis. The American journal of clinical nutrition. 1996;64(3 Suppl):397S-404S. [CrossRef]

4. Selberg O, Selberg D. Norms and correlates of bioimpedance phase angle in healthy human subjects, hospitalized patients, and patients with liver cirrhosis. European journal of applied physiology. 2002;86:509-16. [CrossRef]

5. Rigaud B, Hamzaoui L, Frikha MR, Chauveau N, Morucci JP. In vitro tissue characterization and modelling using electrical impedance measurements in the $100 \mathrm{~Hz}-10 \mathrm{MHz}$ frequency range. Physiol Meas. 1995;16(3 Suppl A):A15-28.

6. Suselbeck T, Thielecke H, Weinschenk I, Reininger-Mack A, Stieglitz T, Metz J, et al. In vivo intravascular electric impedance spectroscopy using a new catheter with integrated microelectrodes. Basic Res Cardiol. 2005;100:28-34. [CrossRef]

7. Brown BH, Tidy JA, Boston K, Blackett AD, Smallwood RH, Sharp F. Relation between tissue structure and imposed electrical current flow in cervical neoplasia. Lancet. 2000;355:892-5. [CrossRef]

8. Farre R, Blondeau K, Clement D, Vicario M, Cardozo L, Vieth M, et al. Evaluation of oesophageal mucosa integrity by the intraluminal impedance technique. Gut. 2011;60:885-92. [CrossRef]

9. Tyagi R, Mishra S, Misra R, Monga YP, Sharma A, Jain A. Bioelectric impedance phase angle as a diagnostic and prognostic marker in carcinoma tongue: A hospital-based study. Natl J Physiol Pharm Pharmacol. 2015;5. [CrossRef]

10. Gonzalez-Correa CA, Brown BH, Smallwood RH, Stephenson TJ, Stoddard CJ, Bardhan KD. Low frequency electrical bioimpedance for the detection of inflammation and dysplasia in Barrett's oesophagus. Physiol Meas. 2003;24:291-6.

11. Lee BR, Roberts WW, Smith DG, Ko HW, Epstein Jl, Lecksell K, et al. Bioimpedance: novel use of a minimally invasive technique for cancer localization in the intact prostate. Prostate. 1999;39:213-8.
12. Morimoto T, Kimura S, Konishi $Y$, Komaki K, Uyama T, Monden $Y$, et al. A study of the electrical bio-impedance of tumors. J Invest Surg. 1993;6:25-32.

13. Malich A, Fritsch T, Mauch C, Boehm T, Freesmeyer M, Fleck M, et al. Electrical impedance scanning: a new technique in the diagnosis of lymph nodes in which malignancy is suspected on ultrasound. $\mathrm{Br} \mathrm{J}$ Radiol. 2001;74:42-7. [CrossRef]

14. Malich A, Fritsch T, Anderson R, Boehm T, Freesmeyer MG, Fleck M, et al. Electrical impedance scanning for classifying suspicious breast lesions: first results. Eur Radiol. 2000;10:1555-61. [CrossRef]

15. Halter RJ, Schned A, Heaney J, Hartov A, Schutz S, Paulsen KD. Electrical impedance spectroscopy of benign and malignant prostatic tissues. J Urol. 2008;179:1580-6. [CrossRef]

16. Haemmerich D, Staelin ST, Tsai JZ, Tungjitkusolmun S, Mahvi DM, Webster JG. In vivo electrical conductivity of hepatic tumours. Physiol Meas. 2003;24:251-60.

17. Faes TJ, van der Meij HA, de Munck JC, Heethaar RM. The electric resistivity of human tissues $(100 \mathrm{~Hz}-10 \mathrm{MHz})$ : a meta-analysis of review studies. Physiol Meas. 1999;20:R1-10.

18. Stoneman MR, Kosempa M, Gregory WD, Gregory CW, Marx J, Mikkelson W, et al. Correction of electrode polarization contributions to the dielectric properties of normal and cancerous breast tissues at audio/radiofrequencies. Phys Med Biol. 2007;52:6589-604. [CrossRef]

19. K'Owino IO, Sadik OA. Impedance Spectroscopy: A Powerful Tool for Rapid Biomolecular Screening and Cell Culture Monitoring. Electroanalysis. 2005;17:2101-13. [CrossRef]

20. Rothermel A, Nieber M, Muller J, Wolf $P$, Schmidt M, Robitzki AA. Real-time measurement of PMA-induced cellular alterations by microelectrode array-based impedance spectroscopy. Biotechniques. 2006;41:445-50. [CrossRef]

21. Varshney M, Li Y. Interdigitated array microelectrodes based impedance biosensors for detection of bacterial cells. Biosens Bioelectron. 2008;2951-60. [CrossRef]

22. Radke SM, Alocilja EC. A high density microelectrode array biosensor for detection of E. coli O157:H7. Biosens Bioelectron. 2005;20:16627. [CrossRef] 